\title{
ZNAČAJNA ULOGA GERIJATRIJE U HRVATSKOJ MEDICINI
}

\author{
NADA TOMASOVIĆ MRČELA ${ }^{1,2}$, BRANKO KOLARIĆ ${ }^{1,3}$
}

Ključne riječi: GERIJATRIJA, GERIJATRIJSKA ZDRAVSTVENA NJEGA

Demografska struktura u Hrvatskoj pokazuje kontinuirani porast starijih osoba u populaciji, tako da je u popisnoj 2001. godini udio osoba od 65 godina $i$ više iznosio $15,6 \%$, a $17,7 \%$ u 2011. godini $(1,2)$. Analogno tome, Hrvatska je uvrštena u skupinu zemalja s "vrlo starim pučanstvom" prema klasifikaciji Ujedinjenih naroda, jer je zastupljeno više od $10 \%$ stanovnika starijih od 65 godina (2). Osobe starije životne dobi čine heterogenu populacijsku skupinu, ali $\mathrm{s}$ većom pojavnosti funkcionalne onesposobljenosti i multimorbiditeta $\mathrm{u}$ odnosu na mlađe dobne skupine $(2,4)$. Rezultati gerontološko-javnozdravstvene analize hospitalizacija u Hrvatskoj (2017. godine) pokazuju da je od ukupnog broja hospitaliziranih bolesnika, udio osoba starijih od 65 godina iznosio čak 36,8\% (3).

Bolesti u osoba starije životne dobi nerijetko imaju atipičan tijek, a pojava simptoma može biti nespecifična ili slabije izražena $(2,4)$. Iz toga proizlaze broj-

${ }^{1}$ Referentni centar Ministarstva zdravstva za zaštitu zdravlja starijih osoba - Služba za javnozdravstvenu gerontologiju, Nastavni zavod za javno zdravstvo "Dr. Andrija Štampar"

${ }^{2}$ Sveučilišni Odjel zdravstvenih studija,

Sveučilište u Splitu

${ }^{3}$ Medicinski fakultet Sveučilišta u Rijeci

Adresa za dopisivanje:

Doc. prim. dr. sc. Nada Tomasović Mrčela, dr. med.

Referentni centar Ministarstva zdravstva za

zaštitu zdravlja starijih osoba - Služba za

javnozdravstvenu gerontologiju Nastavnog zavoda

za javno zdravstvo "Dr. Andrija Štampar"

10000 Zagreb, Mirogojska cesta 16

E-mail: nada.tomasovic@du.htnet.hr ne specifičnosti u mjerama i postupcima prevencije bolesti, liječenja, rehabilitacije i zdravstvene njege za starije osobe. U zaštiti zdravlja starijih osoba nezamjenjiv je model interdisciplinarnog gerontološkog pristupa koji obuhvaća stručnjake različitih profesionalnih profila (2).

Gerijatrija je medicinska specijalizacija koja se bavi dijagnostikom, liječenjem i rehabilitacijom bolesnih starijih osoba te sprječavanjem nastanka bolesti u starijoj dobi (5). Američki liječnik, Ingnaz L. Nascher, prvi je objavio naziv gerijatrija u članku Geriatrics u New York Medical Journal 1909. godine, te se smatra osnivačem moderne gerijatrije (5).

Prema UEMS-u (European Union of Medical Specialists), gerijatrija je zasebna medicinska specijalizacija (6). U Hrvatskoj su izradbu programa medicinske specijalizacije iz gerijatrije inicirali Hrvatsko društvo za gerontologiju i gerijatriju Hrvatskog liječničkog zbora (HD ZGIG HLZ-a) i Referentni centar Ministarstva zdravstva Republike $\mathrm{Hr}$ vatske (MZ RH) za zaštitu zdravlja starijih osoba - Služba za javnozdravstvenu gerontologiju (SJZG) Nastavnog zavoda za javno zdravstvo (NZJZ) "Dr. Andrija Štampar" u 2008. godini (6).

U 2007. godini objavljeno je drugo izdanje krucijalne knjige "Gerijatrija medicina starije dobi", koja predstavlja sveobuhvatnu sintezu specifičnosti u području liječenja, dijagnostike i rehabilitacije osoba starije životne dobi (5). Gerijatrija je Pravilnikom o specijalističkom usavršavanju doktora medicine uvrštena
(Narodne Novine 116/2015) u popis medicinskih specijalizacija u Hrvatskoj (2). Program medicinske specijalizacije iz Gerijatrije traje pet (5) godina (2).

U cilju zadovoljenja zdravstvenih potreba starijih osoba u području zaštite zdravlja i zdravstvene zaštite fokusirano starije populacije, posebno je značajna uloga gerijatrijske zdravstvene njege. Slijedom toga, Referentni centar MZ RH za zaštitu zdravlja starijih osoba - SJZG NZJZ "Dr.Andrija Štampar", uz potporu Hrvatske komore medicinskih sestara, objavio je priručnik: "Četiri stupnja gerijatrijske zdravstvene njege sa sestrinskom dokumentacijom i postupnikom opće/obiteljske medicine u domu za starije osobe" (6).

U Splitu se nedvojbeno konkretno pridonijelo afirmaciji gerijatrije i gerijatrijske zdravstvene njege. Na XI. kongresu liječnika obiteljske medicine u Splitu, već u 2004. godini je predstavljen rad pod naslovom "Nova uloga gerijatrije $u$ zdravstvenoj skrbi Hrvatske" koji je nastao povratkom autorice iz obilaska odjela gerijatrije Policlinico Universitario A. Gemelli di Roma (1). Sveučilišni odjel zdravstvenih studija (SOZS) Sveučilišta u Splitu, prema našim saznanjima, među prvim je zdravstvenim studijima $\mathrm{u} \mathrm{Hr}$ vatskoj u 21. stoljeću koji su gerijatriju i/ ili gerijatrijsku zdravstvenu njegu uvrstili u svoj kurikulum:

- Izborni predmet "Gerijatrija" na preddiplomskom studiju Sestrinstva - prvi put se izvodio u akad. god. 2017./2018. 
- Izborni predmet "Gerijatrija i gerijatrijska zdravstvena njega utemeljena na dokazima", na diplomskom studiju Sestrinstva, prvi put se izvodio u akad. god. 2013./2014.

SOZS Sveučilišta u Splitu je omogućio inovativnu edukaciju iz gerijatrije i gerijatrijske zdravstvene njege utemeljene na dokazima, što predstavlja kontinuirani i autentični doprinos zaštiti zdravlja starijih osoba.

\section{Kratice:}

UEMS - European Union of Medical Specialists HD ZGIG HLZ-a - Hrvatsko društvo za gerontologiju i gerijatriju Hrvatskog liječničkog zbora

MZ RH - Ministarstvo zdravstva Republike Hrvatske

SJZG - Služba za javnozdravstvenu gerontologiju NZJZ - Nastavni zavod za javno zdravstvo

SOZS - Sveučilišni odjel zdravstvenih studija

\section{NOVČANA POTPORA/FUNDING}

Nema/None

ETIČKO ODOBRENJE/ETHICAL APPROVAL

Nije potrebno/None
SUKOB INTERESA/CONFLICT OF INTEREST Autori su popunili the Unified Competing Interest form na www.icmje.org/coi_disclosure.pdf (dostupno na zahtjev) obrazac i izjavljuju: nemaju potporu niti jedne organizacije za objavljeni rad; nemaju financijsku potporu niti jedne organizacije koja bi mogla imati interes za objavu ovog rada u posljednje 3 godine; nemaju drugih veza ili aktivnosti koje bi mogle utjecati na objavljeni rad./ All authors have completed the Unified Competing Interest form at www.icmje.org/coi disclosure. pdf (available on request from the corresponding author) and declare: no support from any organization for the submitted work; no financial relationships with any organizations that might have an interest in the submitted work in the previous 3 years; no other relationships or activities that could appear to have influenced the submitted work.

\section{LITERATURA}

1. Tomasović N, Depolo T. Nova uloga gerijatrije u zdravstvenoj skrbi Hrvatske.U: Petric D, Rumboldt M, ur. Starije osobe u skrbi obiteljskog liječnika, multimorbiditet i politerapija. Zbornik XI kongresa obiteljske medicine; 2004; Split, Hrvatska. Zagreb: HUOM; 2004; 404-9.

2. Tomasović Mrčela N, Tomek-Roksandić S, Šostar Z et al. Razlike između fiziološkog i bolesnog starenja - osnove za gerontološku rehabilitaciju. U: Grubišić F, Vlak T, ur. Fizikalna i rehabilitacijska medicina. 6. Kongres fizikalne i rehabilitacijske medicine; 2016 travanj 14-7. Šibenik, Hrvatska. Zagreb: Hrvatsko društvo za fizikalnu i rehabilitacijsku medicine pri HLZ-u; 2016; 56-67.

3. Stevanović R, Capak K, Benjak T, ur. Hrvatski zdravstveno-statistički ljetopis za 2018. godinu (Internet). Zagreb: Hrvatski zavod za javno zdravstvo; 2019. (citirano 29.03.2021). Dostupno na: https://www.hzjz.hr/wp-content/ uploads/2019/10/Ljetopis_Yearbook_2018.pdf.

4. Duraković Z. i sur. Gerijatrija medicina starije dobi. Zagreb: C.T. - Poslovne informacije, d.o.o. 2007.

5. Kolarić B, Tomek-Roksandić S, Duraković Z et al. Gerijatrija medicinska specijalizacija po UEMS-u i u Hrvatskoj. Knjiga sažetaka 3. hrvatskog gerontološkog i gerijatrijskog kongresa s međunarodnim sudjelovanjem; 2016 studeni 15-7; Opatija, Hrvatska. Zagreb: HLZ; Liječnički vjesnik. 2016; 138 (2): 26.

6. Tomek-Roksandić S, Lukić M, Deucht A et al. Četiri stupnja gerijatrijske zdravstvene njege sa sestrinskom dokumentacijom i postupnikom opće/obiteljske medicine u domu za starije osobe. Zagreb: CZG ZJZ "Dr. Andrija Štampar", 2011.

\title{
Summary
}

\section{IMPORTANT ROLE OF GERIATRICS IN CROATIAN MEDICINE}

\author{
Nada Tomasović Mrčela, Branko Kolarić
}

Keywords: GERIATRIC, GERIATRIC NURSING

Primljeno/Received: 2. 4. 2021.

Prihvaćeno/Accepted: 21. 4. 2021. 